\title{
The Effectiveness of Behavioral Counseling to Reduce Student Learning Anxiety
}

\author{
Taty Fauzi \\ Universitas PGRI Palembang, Indonesia \\ @tatyfauzy@univpgri-palembang.ac.id
}

\begin{abstract}
This is a continuing study of a development behavioral model to help students reduce their learning anxiety. 192 students involved as study population after filled self-report scale of learning anxiety, but only 30 students who had meet the learning anxiety criteria and they were given counseling interventions. Through quasi-experiment pretest-posttest control group design, 30 students divided into two groups, 15 students in the experiment group with behavioral counseling and 15 students in the control group with no specific approach. Overall, there are significant differences between experiment and control group ( $t=-27.65, p<0.05$ ). The results of the proposed study prove that the behavioral counseling model showed higher impact to reduce learning anxiety rather than the conventional counseling with no specific approach. Therefore, the author concludes that behavioral counseling is one of the effective interventions to reduce students learning anxiety. The implication of this research to counseling practice will be discussed.
\end{abstract}

Article Information:

Received June 1, 2020

Revised June 8, 2020

Accepted June 17, 2020

Keywords: behavioral; counseling model; learning anxiety

\section{INTRODUCTION}

Learning behavior is one of the main activities in every educational context. Many research and educational psychology experiments were directed at achieving understanding in learning behavior (Schweder, 2019, 2020). Yen et al. (2004) states that there is a unique relationship between learning behavior and academic achievement. They claimed that students with adaptive learning behavior (i.e confident, motivated, persistent etc.) are likely have higher probability succeed in their academic life. In the opposite, students with learning behavior problems (i.e anxiety, inattention etc) showed lower in academic performance (Brook \& Willoughby, 2015; Plamondon \& Martinussen, 2019).

Barlow (2013) stated anxiety as an uncertainty feeling about fear or worry. In some circumstances, anxiety could be a good thing to be experienced but in moderate amounts. This feeling would give us motivation and excitement about life (Parker \& Ragsdale, 2015). Even though we can use anxiety to improve our performance it can also become serious problem if we experience an intense anxiety which becomes overwhelmed and distracted (Alwisol, 2004). In general, every person might have anxiety in order to protect themselves from things that were not desirable, but if anxiety exceeds the normal threshold such as being afraid of excessively, avoiding or even resigned to receiving the effects of anxiety without any effort to overcome it became a threat to physical and psychological health. In the academic context, abundant research have done and proved that anxiety has negative impact on academic performance or achievement (Brook \& Willoughby, 2015; Eysenck et al., 2007; Plamondon \& Martinussen, 2019; Steinmayr et al., 2016).

In this study, author focus on the appropriate approach how to overcome the anxiety in learning behavior. The prior research conducted by author is about behavioral counseling 
approach (Fauzi, 2020) needs to be examined, the author has made instruction to conduct the counseling for the experiment group. Abundant research conducted in Indonesia tend used cognitive behavioral approach (Kifli et al., 2019; Makhmudah et al., 2019; Setyowati et al., 2019; Situmorang, 2018; Wahyuningsih et al., 2019). Other research has reported that cognitive behavioral counseling effective to reduce students anxiety (Ponsford et al., 2016; Wong et al., 2018).

While study using behavioral counseling approach was very limited and none of them directed to overcome the anxiety in the academic context. For instance, behavioral counseling used to help people with unhealthy alcohol use (O'Connor et al., 2018) and anxiety of inpatients with hepatocellular carcinoma (Wei et al., 2017). None of both prior research use student as samples and focus on academic anxiety. Besides, Pittig et al. (2016) found novel behavioral approach that could enhance the reduction of anxiety. They continued, procedural strategies may enhance the reduction of anxiety by focusing on maximized violation of threat expectancies, increasing variability, and regulating specific emotions. The behavioral counseling approach showed its effectiveness in reducing anxiety (Pittig et al., 2016; Wei et al., 2017) but as stated before, too few to mention that behavioral approach would help the students to overcome their adversity, in particular learning anxiety. Therefore, this study is intended to examine the effectiveness of behavioral counseling approach to reduce students learning anxiety. The author has made the procedures in conducting this counseling approach.

\section{METHODS}

Quasi-experiment pretest posttest control group design utilized to examine the behavioral counseling intervention impact on learning anxiety compared with no specific counseling approach. 192 students from 2 schools in Palembang, South Sumatera, Indonesia were involved as participants. They were given a self-report instrument to assess their level of learning anxiety. 30 students reported with high level of anxiety, the self-report data also used as pretest data. They were divided into two groups, 15 students in experiment group with behavioral counseling intervention and 15 students in control group with counseling no specific approach. Each group given six sessions and 50 minutes of the intervention in each sessions. In the final session, author given the participants the same instrument in the pretest to be filled. The data obtained from this final session called posttest data.

The learning anxiety scale uses likert model with five alternative answers a) very precisely, b) precisely, c) doubtful, d) less precisely, and e) very inappropriate. There are 93 items from five aspects a) participation frequency, b) Unpleasant Communication Experience, c) Self-Avoidance, d) self-control, and e) self-statement. After validity and reliabity test, only 75 items validf. The instrument has good reliability based on the value of product moment correlation $(\alpha=0.94)$. The higher the score obtained by the student the higher their learning anxiety.

The author used t-test to determine the mean differences between experiment with control group. Besides, to determine the differences between experiment with control group in terms of five learning anxiety aspects.

\section{RESULTS AND DISCUSSION}

The gain data normality test showed that all data, both in the experimental group and the control group were from the same population and were normally distributed $(\mathrm{p}>0.05)$. Overall homogeneity of variance in student gain data showed homogeneous variance $(p>$ 0.05). From five aspects of learning anxiety, most often experienced by students are 1) unpleasant communication experiences $(58.85 \%)$, 2) low self-control $(47.40 \%)$, 3) participation frequency (41.67\%). The difference test results showed in Table 1 that the difference in the gain data in the experimental and control groups was significant $(\mathrm{p}<0.05)$. 


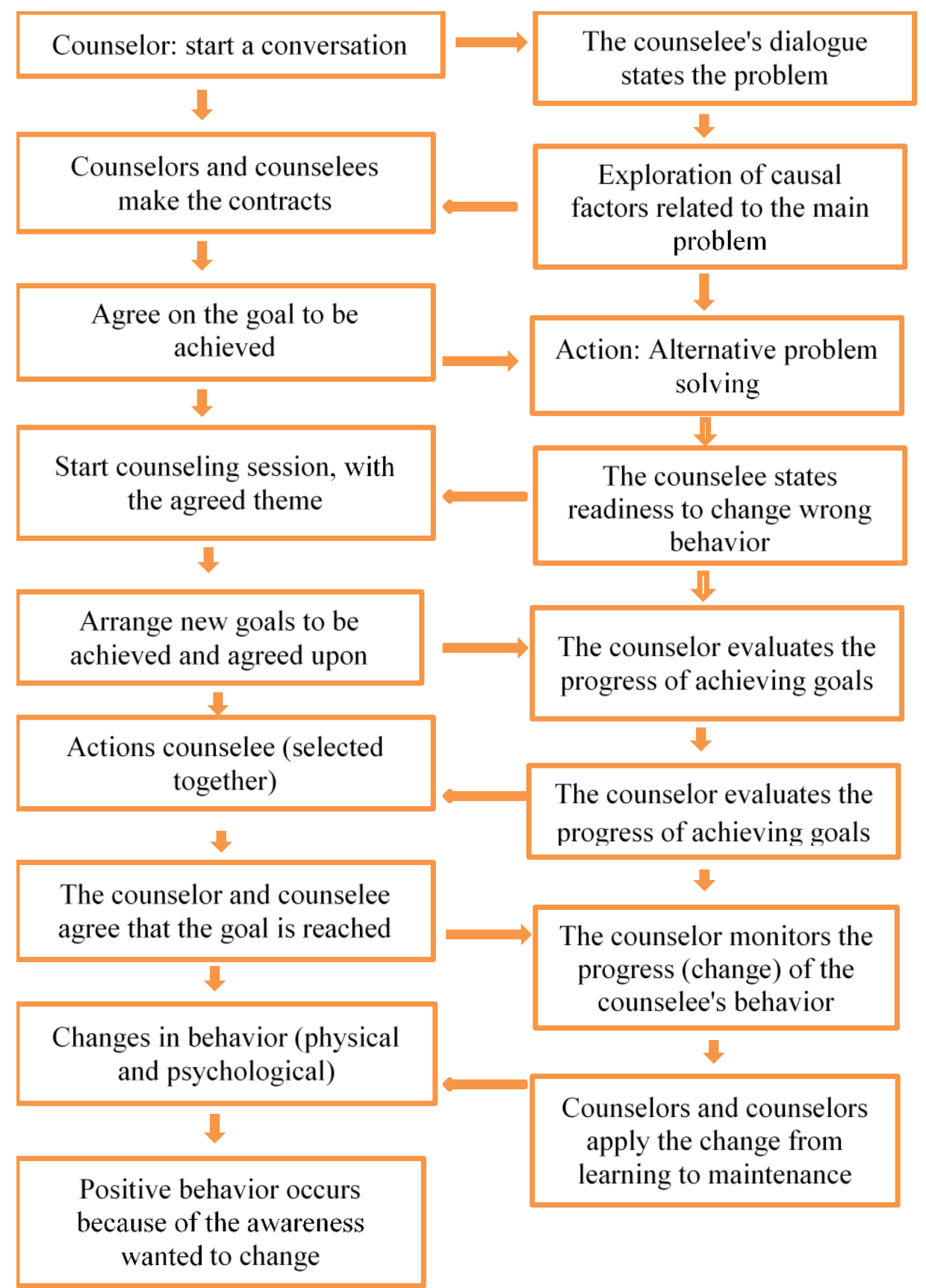

Figure 1. The behavioral counseling procedure (adopted from Pietrofesa et al., 1978)

The results of the behavioral counseling model treatment were effective to help students overcome learning anxiety in Palembang Senior High School. Then the gain test was performed on the Experiment and Control Group.

To find out the differences in the gain data in the experimental group and the control group in each aspect of students' learning anxiety and the t-test result can be seen in the Table 2. The data gain in every aspect of student learning anxiety was significant $(p<0.05)$. Substantially, the behavioral counseling model was effective to help students overcome their learning anxiety.

Based on the results of counseling interventions students who were unable to complete development tasks properly and thoroughly tend to overdo self-defense by making appropriate compensation according to him. The condition got worse when there was a 


\begin{tabular}{cccccc}
\hline Group & Average & SD & $\mathrm{t}$ & $\mathrm{p}$ & Information \\
\hline Experiment & -0.3894 & 0.0759 & \multirow{2}{*}{27.6570} & $<0.05$ & \multirow{2}{*}{ Significant } \\
Control & -0.0022 & 0.0112 & & & \\
\hline
\end{tabular}

Table 1. The Results of difference data gain for Experiment and Control Group

\begin{tabular}{|c|c|c|c|c|c|c|c|c|c|}
\hline \multirow{2}{*}{ Aspects } & \multirow{2}{*}{ Indicators } & \multicolumn{2}{|c|}{ Experiment } & \multicolumn{2}{|c|}{ Control } & \multirow{2}{*}{$\begin{array}{l}\text { Avg } \\
\text { Diff }\end{array}$} & \multirow{2}{*}{$\mathrm{t}$} & \multirow{2}{*}{$\mathrm{p}$} & \multirow{2}{*}{ Information } \\
\hline & & Avg & SD & Avg & SD & & & & \\
\hline \multirow{4}{*}{$\begin{array}{l}\text { Participation } \\
\text { Frequency }\end{array}$} & 1 & -0.796 & 1.787 & 0.003 & 0.018 & -0.800 & -2.411 & 0.019 & Significant \\
\hline & 2 & -0.357 & 0.279 & -0.010 & 0.053 & -0.348 & -6.598 & 0.000 & Significant \\
\hline & 3 & -0.763 & 0.820 & -0.041 & 0.127 & -0.722 & -4.683 & 0.000 & Significant \\
\hline & 4 & -0.449 & 0.386 & -0.001 & 0.072 & -0.447 & -6.141 & 0.000 & Significant \\
\hline \multirow{2}{*}{$\begin{array}{c}\text { Unpleasant } \\
\text { Communication }\end{array}$} & 1 & -0.742 & 1.185 & 0.000 & 0.000 & -0.742 & -3.378 & 0.001 & Significant \\
\hline & 2 & -0.491 & 0.603 & 0.000 & 0.000 & -0.491 & -4.375 & 0.000 & Significant \\
\hline \multirow{3}{*}{ Self-Avoidance } & 1 & -0.291 & 0.314 & 0.000 & 0.000 & -0.291 & -4.956 & 0.000 & Significant \\
\hline & 2 & -0.426 & 0.239 & 0.000 & 0.000 & -0.426 & -9.615 & 0.000 & Significant \\
\hline & 3 & -0.544 & 0.602 & 0.000 & 0.000 & -0.544 & -4.865 & 0.000 & Significant \\
\hline \multirow{3}{*}{ Self-Control } & 1 & -0.874 & 0.951 & 0.000 & 0.000 & -0.874 & -4.95 & 0.000 & Significant \\
\hline & 2 & -0.606 & 0.614 & 0.005 & 0.028 & -0.612 & -5.352 & 0.000 & Significant \\
\hline & 3 & -0.383 & 0.373 & 0.003 & 0.015 & -0.385 & -5.546 & 0.000 & Significant \\
\hline \multirow{3}{*}{ Self-Statement } & 1 & -0.605 & 0.759 & 0.003 & 0.018 & -0.608 & -4.315 & 0.000 & Significant \\
\hline & 2 & -0.925 & 2.291 & -0.010 & 0.049 & -0.915 & -2.152 & 0.036 & Significant \\
\hline & 3 & -0.346 & 0.417 & 0.008 & 0.031 & -0.354 & -4.559 & 0.000 & Significant \\
\hline
\end{tabular}

stereotype of the teacher in the learning process, a lack of reinforcement from both the teacher and parents. In the indicator of blaming others students saw other people as the cause of anxiety as a form of self-defense mechanism (ego defense mechanism), students also demand more attention. This attitude was psychologically one of the characteristics of adolescents, the ego appeared excessively, so they perceived that others might always understand them (irrational beliefs).

The results of this study are in line with research Depiani et al. (2014) that behavioral counceling effective for minimizing anxiety. The samples were taken by using multy stage sampling technique with 20 students. The data of this study was the data of student anxiety, which obtained by questionnaire and observation methods to see the students who have high anxiety. Anxiety Data were analyzed with descriptive analysis and t-test (independent t-test). All hypothesis testing conducted on the 5\% significance level. The results showed there were differences in the effectiveness of behavioral counseling with modeling $(t=0,925 ; \mathrm{p}<0.005)$. Based on the analysis, it was found that: The average normalized gain scores for Systematic Desensitization Technique was -31.42 and the standard deviation was 3.423 . While the average of normalized gain scores for Mechanical Modeling was -34.02 and the standard deviation was 3.978. It showed that there were differences in the effectiveness of behavioral counseling desensitization systematic with modeling to minimized the test anxiety.

School conditions and teacher attitudes in the learning process can be a trigger for problems. Teachers as educators must open themselves to all students without any conditions with all the characteristics students have during their development. Testing the effectiveness of the behavioral counseling model in reducing the level of learning anxiety added to the succession of behavioral counseling as a mode of intervention. Teachers as educators should 
open themselves to all students without conditions with all the characteristics possessed by students during their development. Testing the effectiveness of the behavioral counseling model in reducing the level of learning anxiety added to the succession of behavioral counseling as a mode of intervention. The power of the behavioral counseling model appeared during successful interventions to train individuals to learn to solve problems and learned to understand others. Intervention targets that emphasized the importance of cognitive work and private events became mediations in change. For the short term behavioral counseling was quite effective in reducing symptoms, whereas in the long run it could produce specific internal predispositions.

Essentially the decline could occur in several intervention sessions, but changes in personality dimensions were not enough evidence, until the intervention session ends. More complete data was needed to make a statement of the long-term impact of counseling interventions and generalizations to validate the effectiveness of cognitive behavioral counseling procedures. For short-term counseling processes could facilitate changes in anxiety in the face of tests, lack of social skills, low assessment of self-esteem, and life satisfaction. The results of this study also refered to the research of Brackney \& Karabenick (1995), they found that psychopathology (psychological pressure) was high with limited coping resources simultaneously, related to student academic performance. However, psychopathology was significantly related to motivation and the use of learning strategies related to academic performance. Specifically, students with bad adjustments consider themselves less competent to succeed, experience greater exam anxiety, and were less likely to regulate their learning environment, survive in the face of difficulties, and seek academic assistance when needed. They were also proved that psychopathology had a significant indirect effect on performance and showed the important role of self-efficacy and resource management.

Anxiety in the behaviorist view is interpreted as negative habits or inappropriate behavior. Anxiety needs to be maintained. Anxiety relieve is not just getting short-term satisfaction, but able to deal with broader difficulties in the longer term. The purpose of counseling is to formulate specific behaviors to be achieved. One of therapies that have proven their effectiveness in dealing with social anxiety is Behavioral Cognitive Therapy. (Asrori, 2016; Kifli et al., 2019; Makhmudah et al., 2019; Setyowati et al., 2019; Situmorang, 2018; Wahyuningsih et al., 2019) their research was conducted to see how cognitive behavioral therapy reduces anxiety. The researchers conducted behavioral cognitive therapy, managed to reduce anxiety by changing negative thought to more positive and rational thinking. Positive and rational thought can make the participants feel more comfortable and less anxious, participants became braver and more confident when facing various social situations that have been they anxious.

Furthermore, Rosmawati (2017) research results show that the impact of anxiety experienced by students are psychological such as dizziness, and not being able to sleep, while the factors that cause student anxiety are learning achievements that are not in line with expectations, unable to adjust with subjects, do not have educational aspirations, and worried about the future, the supervisor has not used the right approach in dealing with students who experience academic problems, the approach is still partial, incidental, routine, counseling service approaches that are carried out by the guidance and counseling teacher in conducting anxiety management has not been effective.

Some weaknesses of behavioral counseling (Erford, 2016) included manipulative, less touching personal aspects, interpersonal relationships were often overlooked, and the goals were more often determined by the counselor. Another weakness was the lack of appreciation in the past counselee. This study only involved students as the main subject under study. Teacher responses and opinions, as well as school tools related to learning anxiety problems 
tend not to be accommodated as a whole. Research only relied on self-report, retrospective techniques in measuring student learning anxiety levels.

The formation of a control group and a treatment group was likely to have a psychological impact, although at the beginning of the formation given freedom to students to choose. This condition allowed differences to the process of student learning activities. Ideally after being treated, student behavior could continue to be monitored systemically to see the consistency of treatment results. There needed to be a flexible adjustment to the conditions of the Indonesian people, in the implementation of counseling sessions where the number of meetings was at least done into 5 sessions with duration of 50 to 60 minutes, if too long students would become bored. Bias might occur, because behavioral counseling taught more skills on the counselee than reducing symptoms, changes in symptoms did not appear in a short time, changes would occur in a matter of weeks and months, especially symptoms related to traits, and personality characteristics.

The results of the study were more representative and quality if the subjects involved in the research on the development of behavioral models were all high school students in Palembang, so as to be able to uncover the factors associated with the emergence of learning anxiety as a fact that was generally accepted and experienced by all students. Behavioral counseling model as the main instrument in reducing the level of student learning anxiety was thought to be one of the factors that influenced the decrease in anxiety. The application of behavioral counseling model was getting stronger with the support of Indayani et al. (2014) research on the application of behavioral counseling with positive strengthening techniques as an effort to minimize truant behavior. The results showed a decrease in truant behavior after being given the intervention.

The recommendations of this study were aimed to guidance and counseling teachers, in order to create a pleasant learning atmosphere, avoid psychological conflicts that could cause learning anxiety because it could affect the learning climate in the classroom, therefore ideally counseling guidance teachers could provide information services not only to students but also to the teacher, as input material that communication interaction and treatment of students was one of the factors causing learning anxiety. Ideally the socialization of guidance and counseling services should be carried out from the outset of students being accepted in the school environment and evenly scheduled, the goal being that students felt "familiar" with the guidance and counseling function as a container that could be used as a reference for a place of consultation. After the implementation of counseling interventions there needed to be an effort to monitor and evaluate the learning behavior of students, so it was possible to see how much and the magnitude of the results of changing the behavior of students towards learning outcomes.

Besides the findings, this study also has limitations 1) only carried out in limited groups, 2) less supported by adequate facilities so that the counseling session may be influenced by facilities, infrastructure and environment that is less conducive, 3) self-report instrument might has biases. Hopefully, further research examine participants more broadly, not only students but may also be teachers or counselors who experience burnout or anxiety in the teaching and learning process at school. So that, behavioral models can be generalized to all people who experience anxiety.

\section{CONCLUSIONS}

Analysis result of the behavioral counseling model effectiveness proved the decrease in learning anxiety of various aspects and indicators of learning anxiety. Based on the results of theoretical and empirical considerations, a behavioral counseling model could be considered as a framework of work reference in the practice of guidance and counseling services in schools to help students overcome learning anxiety. 


\section{ACKNOWLEDGEMENTS}

Author sincere her gratitude to Universitas PGRI Palembang. As well as to Research and Community Service Institute of Universitas PGRI Palembang for its administrative assistance in completing this article.

\section{AUTHOR CONTRIBUTIONS STATEMENT}

FT is the single author and researcher for this article. FT declares that she has no any conflict of interests.

\section{REFERENCES}

Alwisol, M. (2004). Psikologi kepribadian. Malang: Universitas Muhammyadiah Malang. Retrieved from Google Scholar

Asrori, A. (2016). Terapi Kognitif Perilaku Untuk Mengatasi Gangguan Kecemasan Sosial. Jurnal Ilmiah Psikologi Terapan, 3(1), 89-107. https://doi.org/10.22219/jipt.v3i1.2128

Barlow, D. H. (2013). Anxiety and its disorders: The nature and treatment of anxiety and panic. Guilford Publications. Retrieved from Google Scholar

Brackney, B. E., \& Karabenick, S. A. (1995). Psychopathology and academic performance: The role of motivation and learning strategies. Journal of Counseling Psychology, 42(4), 456-465. https://doi.org/10.1037/0022-0167.42.4.456

Brook, C. A., \& Willoughby, T. (2015). The Social Ties That Bind: Social Anxiety and Academic Achievement Across the University Years. Journal of Youth and Adolescence, 44(5), 1139-1152. https://doi.org/10.1007/s10964-015-0262-8

Depiani, K. M., Prof. Dr. Ni Ketut Suarni, M. S., \& Dewi Arum Widhiyanti Metra Putri, S. P. (2014). Efektivitas Konseling Behavioral Dengan Teknik Desensitisasi Sistematis Dan Modeling Untuk Meminimalisasi Kecemasan Dalam Menghadapi Prakerin Siswa Kelas XI Tata Boga Di SMK Negeri 2 Singaraja Tahun Pelajaran 2013/2014. Jurnal Ilmiah Bimbingan Konseling Undiksha, 2(1), Article 1. https://doi.org/10.23887/jibk.v2i1.3730

Erford, B. T. (2016). 40 Techniques Every Counselor Should Know. Prentice Hall.

Eysenck, M. W., Derakshan, N., Santos, R., \& Calvo, M. G. (2007). Anxiety and cognitive performance: Attentional control theory. Emotion, 7(2), 336-353. https://doi.org/10.1037/1528-3542.7.2.336

Fauzi, T. (2020). Pengembangan Model Konseling Behavior untuk Mengurangi Kecemasan Belajar Siswa [Unpublished Research Report]. Universitas PGRI Palembang.

Indayani, A., Prof. Dr. Gede Sedanayasa, M. P., \& Dra. Ni Nengah Madri Antari, M. E. (2014). Penerapan Konseling Behavioral Dengan Teknik Penguatan Positif Sebagai Upaya Untuk Meminimalisasi Perilaku Membolos Pada Siswa KelaS X.1 SMA Negeri 1 Sawan Tahun Ajaran 2013/2014. Jurnal Ilmiah Bimbingan Konseling Undiksha, 2(1), Article 1. https://doi.org/10.23887/jibk.v2i1.3916

Kifli, I., Sunawan, S., \& Jafar, M. (2019). Cognitive Behavior Group Counseling to Reduce Academic Anxiety. Jurnal Bimbingan Konseling, 8(2), 119-124. https://doi.org/10.15294/jubk.v8i2.28170

Makhmudah, A. N. L., Wibowo, M. E., \& Awalya, A. (2019). Cognitive Behavior Group Counseling with Cognitive Restructuring and Problem Solving Techniques to Reduce Anxiety. Jurnal Bimbingan Konseling, 8(2), 174-181. https://doi.org/10.15294/jubk.v8i2.28489

O’Connor, E. A., Perdue, L. A., Senger, C. A., Rushkin, M., Patnode, C. D., Bean, S. I., \& Jonas, D. E. (2018). Screening and Behavioral Counseling Interventions to Reduce Unhealthy Alcohol Use in Adolescents and Adults: Updated Evidence Report and 
Systematic Review for the US Preventive Services Task Force. JAMA, 320(18), 1910 1928. https://doi.org/10.1001/jama.2018.12086

Parker, K. N., \& Ragsdale, J. M. (2015). Effects of Distress and Eustress on Changes in Fatigue from Waking to Working. Applied Psychology: Health and Well-Being, 7(3), 293-315. https://doi.org/10.1111/aphw.12049

Pittig, A., van den Berg, L., \& Vervliet, B. (2016). The key role of extinction learning in anxiety disorders: Behavioral strategies to enhance exposure-based treatments. Current Opinion in Psychiatry, 29(1), 39-47. https://doi.org/10.1097/YCO.0000000000000220

Plamondon, A., \& Martinussen, R. (2019). Inattention Symptoms Are Associated with Academic Achievement Mostly Through Variance Shared with Intrinsic Motivation and Behavioral Engagement. Journal of Attention Disorders, 23(14), 1816-1828. https://doi.org/10.1177/1087054715587098

Ponsford, J., Lee, N. K., Wong, D., McKay, A., Haines, K., Alway, Y., Downing, M., Furtado, C., \& O'Donnell, M. L. (2016). Efficacy of motivational interviewing and cognitive behavioral therapy for anxiety and depression symptoms following traumatic brain injury. Psychological Medicine, 46(5), 1079-1090. https://doi.org/10.1017/S0033291715002640

Rosmawati, R. (2017). Penerapan Layanan Konseling Untuk Mengatasi Kecemasan Siswa. JURKAM: Jurnal Konseling Andi Matappa, 1(1), 39-45. https://doi.org/10.31100/jurkam.v1i1.4

Schweder, S. (2019). The role of control strategies, self-efficacy, and learning behavior in self-directed learning. International Journal of School \& Educational Psychology, 7(sup1), 29-41. https://doi.org/10.1080/21683603.2018.1459991

Schweder, S. (2020). Mastery goals, positive emotions and learning behavior in self-directed vs. Teacher-directed learning. European Journal of Psychology of Education, 35(1), 205-223. https://doi.org/10.1007/s10212-019-00421-z

Setyowati, A., Rayaginansih, S. F., Fahriza, I., \& Fauziah, M. (2019). Behavioral Cognitive Counseling for Reducing Test Anxiety Among University Students. 211-215. https://doi.org/10.2991/icei-19.2019.17

Situmorang, D. D. B. (2018). How Does Cognitive Behavior Therapy view an Academic Anxiety of the Undergraduate Thesis? Islamic Guidance and Counseling Journal, 1(2), 69-80. https://doi.org/10.25217/igcj.v1i2.221

Steinmayr, R., Crede, J., McElvany, N., \& Wirthwein, L. (2016). Subjective Well-Being, Test Anxiety, Academic Achievement: Testing for Reciprocal Effects. Frontiers in Psychology, 6. https://doi.org/10.3389/fpsyg.2015.01994

Wahyuningsih, E., Sunawan, S., \& Awalya, A. (2019). The Effectiveness of Cognitive Behavior Therapy Counseling to Reduce the Social Anxiety of Blind Students. Jurnal Bimbingan Konseling, 8(2), 188-196. https://doi.org/10.15294/jubk.v8i2.28493

Wei, Y., Li, A., Huang, Y., Zhao, X., Tang, J., Mo, Z., \& Pang, Y. (2017). Correlation analysis between psychological counseling behaviors of accompanying family members and anxiety and depression of inpatients with hepatocellular carcinoma. Chinese Journal of Practical Nursing, 33(8), 602-607. Retrieved from Google Scholar

Wong, D. F. K., Kwok, S. Y. C. L., Low, Y. T., Man, K. W., \& Ip, P. S. Y. (2018). Evaluating Effectiveness of Cognitive-Behavior Therapy for Hong Kong Adolescents with Anxiety Problems. Research on Social Work Practice, 28(5), 585-594. https://doi.org/10.1177/1049731516658351

Yen, C.-J., Konold, T. R., \& McDermott, P. A. (2004). Does learning behavior augment cognitive ability as an indicator of academic achievement? Journal of School Psychology, 42(2), 157-169. https://doi.org/10.1016/j.jsp.2003.12.001 
The Effectiveness of Behavioral Counseling to Reduce Student Learning Anxiety

\author{
Copyright holder : \\ (C) Fauzi, T. (2020) \\ First publication right : \\ (C) Islamic Guidance and Counseling Journal \\ This article is licensed under: \\ CC-BY-SA
}

